\title{
Import Competition and Export Dual Margins of Multi-Product Firms
}

\author{
Jianhuan Ouyang \\ College of Economics, Jinan University, Guangzhou, China \\ Email: ouyangjh1991@hotmail.com
}

Received 8 March 2016; accepted 18 April 2016; published 21 April 2016

Copyright (C) 2016 by author and Scientific Research Publishing Inc.

This work is licensed under the Creative Commons Attribution International License (CC BY). http://creativecommons.org/licenses/by/4.0/

c) (i) Open Access

\begin{abstract}
Using the matching panel data of Chinese industrial database and Custom database in the period of 2000-2006, this paper studies the relationship between import competition and dual exporting margins of multi-product firm. This study finds that: import competition improves the intensive and extensive margins significantly, even stronger to the intensive margin.
\end{abstract}

\section{Keywords}

Competition Effect, Import Competition, Core Competencies, Dual Margins, Multi-Product Firms

\section{Introduction}

China has experienced long and profound trade liberalization. The non-weighted tariff from the beginning of reform and opening up was about $55 \%$, then went down to $18 \%$ when it joined the WTO, and went down to $9 \%$ in 2006. The rapid decline in the cost of trade has brought about a surge in imports, which has brought significant import competition. On the other hand, during the period China entered WTO from 2000 to 2006, Chinese multi-product export enterprises accounted for more than $80 \%$ of all export enterprises, and exports accounted for more than $90 \%$. As we can see, the main force of Chinese exports is multi-product firms. So, what is the relationship between the typical two characteristics of China: the import competition and multi-product export enterprises?

Some existing literatures have studied the relationship between import competition and export margin. Bernard, Redding and Schott [1] using a general equilibrium model of embedded multi-product firms, found that despite the trade liberalization, the enterprise product range narrowed, but the export intensity increased, and all remaining products were exported. In other words, the trade cost reduction brought by the trade liberalization will also increase the export's intensive margin and the extensive margin of the multi-product enterprises. Decramer, Fuss and Kornings [2] using unit labor costs as a proxy for international competition, found that the unit 
labor cost is negatively correlated with the performance of export enterprises, and the intensive margin and extensive margin are negatively correlated. Miranda, Badia and Beverenet [3] using the firm-level panel data of Estonia, found that the multi-product firms cope with international competition through product line adjustment, and switch their own core products according to export opportunities. The difference between these documents and this paper lies in the focus of perspective. The former mainly focuses on how enterprise adjusts the margins in the export market facing competition, and this paper is focusing on enterprises facing foreign competition in the domestic market and how their performances will be effected in the export market.

In this paper, we study the influence of import competition on dual export margins of multi-product firm. As far as I know, the current domestic research has not used the micro firm-level data on this issue. The remainder of this paper is arranged as follows: the second part discusses the impact mechanism and related research hypothesis. The third part introduces the measurement model and data description. The fourth part reports the empirical results. The last is the conclusion.

\section{Influence Mechanism and Research Hypothesis}

\subsection{The Analysis of Influence Mechanism}

Import competition promotes the increase of dual export margins of multi-product firm, mainly through the following ways.

1) Reduce the markup of the domestic market. Import competition makes the types of products on the domestic market more abundant, consumers have more choices Domestic manufacturers in order to remain competitiveness, will be forced to low prices. The firm will firstly drop the products with lowest markup, and then reallocate resources to the products with higher markup.

2) Reduce the scale of enterprises. Tyout [4] pointed out by import competition enterprises will reduce the scale of production. Import competition will compete in the domestic market share, the original market share of domestic producers declines, thereby reducing the company's sales. Enterprise sales decline will make the inventory increase, forcing enterprises to reduce production and scale. The product with the weakest profitability will be the first to cut production scale, so as to promote the re allocation of resources within the enterprise.

3) Demonstration effect and learning effect. Although imported competitors increase operating pressure of the domestic manufacturers, but domestic manufacturers can get more information on their opponents, so as to develop marketing strategy, optimize product categories.

4) Reallocation of resources within the industry. Meiltz [5], the single product heterogeneous firm model show that import competition by trade liberalization promotes the resource reallocation within industry, firms with the lowest productivity exit, high productivity firms enter into the export market, so as to improve the overall productivity. The improvement of the overall productivity means that the average level of productivity of enterprises in the industry increase. In order to maintain their competitiveness, Enterprises must strive to improve the level of their productivity, so as to stimulate the enterprises to adjust the strategy, re allocate enterprise resources.

The vast majority of enterprises are multi product enterprises, when facing the impact of import competition, the enterprise can adjust the product line to withstand the impact, that is, the within firm resource reallocation. Multi product firm model reveals a new welfare mechanism. Bernard, Redding and Schott [1] reveals that trade liberalization brings the reduction of trade cost, which is positive correlative to export intensive margin and export extensive margin of multi-product firm On the other hand, the decline in trade costs (import market) will bring more intense import competition. Enterprises will discard product categories with the lowest production experience, then strengthen the core products and reallocate resources to other product categories with higher production experience, thus raising the average productivity of products and increasing export dual margins.

For China's manufacturing industry, the long-term export oriented policy makes the export products of manufacturing enterprises, are mainly its core products. While the domestic market due to greater protection, is full of enterprise edge products When trade liberalization makes the import competition intensifies, domestic manufacturers' edge products in the domestic market will be the first to be hit, products with the worst quality will lose market share then abandoned by enterprises. And the products that have been retained have more opportunities for production input and quality improvement on average. In other words, in the face of more intense domestic competition, manufacturing enterprises will take strategy to strengthen the core product, so as to reallocate more resources on export production and domestic high quality products, then the intensive margin growth 
can be observed. The rise in the average quality of products enables more types of products to overcome the fixed cost of export, to enter the export market, and then the growth of the export extensive margin of firm can be observed.

\subsection{Hypothesis}

Based on the analysis of micro influence above, this paper puts forward the following basic hypothesis: the higher the degree of import competition in the domestic market, the more able to stimulate the dual export margins of multi-product firms.

The higher the degree of import competition in the domestic market, the impact on the product category of multi-product enterprises in domestic sales is stronger. The edge products with low production efficiency will lose market share, while the core products in domestic market and export products will avoid the import competition Enterprises through the internal resources reconfiguration, the production resources are more allocated to the core product and export products. Thus the original export products can grow along the intensive margin, while the original core products sold in the domestic market can overcome the fixed cost of exports, then export product types increased, so that export can grow along the extensive margin.

\section{Econometric Model and Data Description}

\subsection{Hypothesis Econometric Model}

This paper builds the following econometric model.

$$
\begin{aligned}
\ln Y_{i j k t}= & \alpha_{0}+\alpha_{1} * \ln \text { impFilt }_{j k t}+\alpha_{2} * \ln \operatorname{TFP}_{i j k t}+\alpha_{3} * \ln \text { Capital }_{i j k t}+\alpha_{4} * \ln \text { Skill }_{i j k t} \\
& +\alpha_{5} * \ln \text { Markup }_{i j k t}+\alpha_{6} * \ln H H I_{j k t}+\theta_{i}+\theta_{t}+\varepsilon_{i j k t}
\end{aligned}
$$

The subscript $i, j, k$ and $t$ respectively represents enterprises, industries, regions and time. The subscript $i$ represents the firm-level fixed effects, which means the firm heterogeneity factors stable with time. $\theta_{t}$ represents the time fixed effects, which means the factors of macroeconomic fluctuations and other factors in each year. $\varepsilon_{i j k t}$ is the error term. Continuous variables are in logarithmic form into the regression equation.

$\ln Y_{i j k t}$ is firm export dual margin, using Bernard, Redding and Schott (2012) [1] decomposition method, the total export amount of the multi-product firms decomposes into four parts, that is the number of export destination, the number of export products species, the export cover rate, and product-destination average export volume.

ln impFilt ${ }_{j k t}$ is import permeability, the calculation method is based on group divided by the 4 digit industry code, province and year, then calculate the quotient of total import and total production within group. Because of there is great difference of tariff rate and other non-tariff trade barrier in various industries, and different regions have its own openness to import, this paper calculate the import penetration of different industries and regions respectively. According to Harrison (1994) [6], the import penetration rate can be a more comprehensive measure of the degree of trade liberalization. In addition, the import penetration rate calculated at the industry level can be used as a proxy variable for import competition. The trade volume unit in customs import database is thousands of dollars, but the output volume unit in the industrial database is thousands of Yuan, so the author used exchange rate data to adjust them. According to the theoretical expectation of Bernard, Redding and Schott (2012) [1] model, enterprise after trade liberalization, product range will be narrowed, but each product accounts for the relative share will rise and all products were involved in the export market. Therefore, the expected import penetration and export intensive margin is positive correlative, and the relationship between import penetration rate and export extensive margin depends on the product dynamic of firm, which needs the help of empirical research on screening.

$\ln T F P_{i j k t}$ is total factor productivity of enterprises. Estimated total factor productivity by using the two step estimation method of Olley and Pakes [7] which embedded production probability, and modified the simultaneous bias and the selectivity bias. In the theory of multi-product export enterprise of Bernard, Redding and Schott (2012) [1], the enterprise productivity is no longer determined by a single enterprise parameter, but determine together by the enterprise, product and country. The stronger the enterprise level ability, the higher the productivity of the enterprise in all its products. Therefore, productivity is positive correlative with the intensive margin and the extensive margin of the firm's export. According to the theoretical model, the higher productivity of en- 
terprise, the higher its export extensive margin. According to the existing similar studies (Bernard, Redding and Scott, 2012) [1], expected TFP is positive correlative with export intensive margin and extensive margin.

$\ln _{\text {Capital }_{i j k t}}$ is the enterprise's capital density, the calculation method for the enterprise is real capital stock divided by the enterprise's output value. The higher the capital intensity of the enterprise, the enterprise is more bias to the capital intensive products. This type of product in China does not have the comparative advantage of exports, so the capital intensity is expected to be negatively related to dual export margins.

ln Skill $l_{i j k t}$ is the enterprise technology intensity, which is defined as the ratio of labor expenditure and output. The report of industrial database in real wages will underestimate the human capital returns; this paper calculates the efficient wage of each firm according to the Hsieh and Klenow [8]. Thus the enterprise technology intensity is the ratio of enterprise efficiency wage and total output value. Technology intensity reflects the proportion of the labor force of an enterprise products input, the higher the degree of technology intensity, labor-intensive features is more obvious. Considering China's exports of labor-intensive products have a strong comparative advantage, so the expected technology intensive products and export intensive margin and extended marginal positive correlation.

$\ln$ Markup $_{i j k t}$ is markup of a firm. The method of definition is enterprise income/(enterprise income-enterprise profit). Markup reflects the enterprise monopoly profits, the higher the level of enterprise cost, the stronger the enterprise to overcome the fixed costs of exports. It is expected that markup is positive correlative with dual export margins.

$\ln H H I_{j k t}$ is the Herfindahl index within the group industry-province-year, which reflect the degree of competition in market production concentration and the competitive degree between enterprises The higher the concentration of an industry, the greater the difficulty of the operation of enterprises, thus limiting the export capacity of enterprises. Therefore, it is expected that the Herfindahl index is negatively correlated with the export margin of enterprises. Using the output value deflated with the price index of each enterprise as a weight to calculate the market share of the enterprise in the area and industry where it is located.

In addition to the above variables, this paper also constructs three virtual variables that represent the ownership of the enterprise, whether it is state-owned, foreign capital or private enterprise. First, through the enterprise attribute code classification, and then further through the proportion of enterprise's real collected capital to classify. Finally, only if the results of the two methods are consistent, to mark the corresponding dummy variable to 1.

\subsection{Data Description}

In this paper, we use the data set that combing 2000-2006 Chinese industrial enterprise databases and the customs import and export database, then select manufacturing enterprises which the 2 digit industry code is among 13 and 43, as the research object. In the process of the industrial database, mainly refer to Bernard, Redding and Schott [1], which outputs is the index of total industrial output value; labor input is the indicator of "annual average employment"; intermediate input is the middle input index; capital stock is based on the fixed asset net value and fixed assets original price, assuming depreciation rate of $9 \%$, then estimate with the perpetual inventory method. Input and output are processed by price deflated adjustment.

In the process of data cleaning, the author deleted observations with the underlying conditions: 1) output value, labor input, capital stock and intermediate input, anyone in them is negative or default; 2) the labor input is less than 8.

Customs import and export database is collected by the General Administration of China Customs every month, every transaction has a record of 8 digit HS code. In this paper, the enterprise product category is defined as the number of 6 digit HS code, that is, a HS-6 code is corresponded to a product category, regardless of where this type of product exports to. The HS encoding is adjusted to 6 digit level, and the monthly data is summed up to annual data.

The author incorporated industrial database and customs database, based on the annual corporate name to match, then using the annual postal code and the last 7 digit of telephone number as complement, in order to improve the matching rate.

In the measurement of the dual export margins, referring to the marginal decomposition method in Bernard, Redding and Schott [1], the total amount of the export trade of each enterprise in the industry is decomposed into 4 dimensions. Respectively, the number of export destinations, the number of types of export products, the export coverage and the average export volume of the product and destination. 


\section{The Results of the Empirical Analysis}

Table 1 is the result of the regression of empirical model Equation (1) with the two way fixed panel model. Column 1 to 5, variables were enterprise exports lnexp Value and enterprise export destination-products average $\ln X f$ is the intensive margin, as well as the expansion of marginal that export enterprises covering rate of $\operatorname{lnDf}$, enterprises export destination number lnexp Country and enterprises to export goods quantity lnexp Good. The regression results show that the import penetration rate of the industry is significantly positively correlated with the export of the enterprises. Suggesting that trade liberalization improves the level of competition in domestic market, causing the impact on the products of domestic enterprises in the domestic market, so as to stimulate the enterprise resource re-configuration, so that enterprises increase exports in existing export intensive margin. At the same time, enterprises are promoted to more actively explore new foreign markets, increase the number of export destinations. Import competition also enable enterprises to give up edge products that do not have a competitive advantage in the domestic market, and will stimulate the allocation of resources to a core products with competitive advantage, so as to improve the resource allocation efficiency in the enterprise, then more kinds of products can overcome fixed export costs, increasing the types of enterprises to export goods. The above two ways contribute for enterprises to expand the marginal increase. The contribution of the intensive margin is $69 \%$, and the contribution from the extensive margin is $31 \%$, which shows that the import competition is mainly through the intensive margin to increase export. But the export contribution of import competition through the extensive margin cannot be ignored.

Table 1. The regression results of two-way fixed panel model.

\begin{tabular}{|c|c|c|c|c|c|}
\hline Variables & $\ln$ Exp Value & $\ln X f$ & $\ln D f$ & $\ln \operatorname{Exp}$ Country & $\ln E x p$ Good \\
\hline \multirow[t]{2}{*}{$\operatorname{lnImpFilt}$} & $0.0873^{* * * *}$ & $0.0606^{* * * *}$ & $-0.0112^{* * *}$ & $0.0191^{* * *}$ & $0.0188^{* * *}$ \\
\hline & $(0.00)$ & $(0.00)$ & $(0.00)$ & $(0.00)$ & $(0.00)$ \\
\hline \multirow[t]{2}{*}{$\ln T F P$} & $0.178^{* * *}$ & $0.0875^{* * *}$ & $-0.0440^{* * *}$ & $0.0788^{* * *}$ & $0.0561^{* * *}$ \\
\hline & $(0.00)$ & $(0.00)$ & $(0.00)$ & $(0.00)$ & $(0.00)$ \\
\hline \multirow[t]{2}{*}{ InCapital Intensity } & $-0.322^{* * *}$ & $-0.225^{* * *}$ & $0.0317^{* * *}$ & $-0.0705^{* * *}$ & $-0.0579^{* * *}$ \\
\hline & $(0.00)$ & $(0.00)$ & $(0.00)$ & $(0.00)$ & $(0.00)$ \\
\hline \multirow[t]{2}{*}{ lnSkill Intensity } & $0.0912^{* * *}$ & $0.0377^{* * *}$ & $-0.0242^{* * *}$ & $0.0426^{* * *}$ & $0.0350^{* * *}$ \\
\hline & $(0.00)$ & $(0.00)$ & $(0.00)$ & $(0.00)$ & $(0.00)$ \\
\hline \multirow[t]{2}{*}{ lnMarkup } & $0.501^{* * *}$ & $0.411^{* * *}$ & $-0.0339^{* * *}$ & $0.0513^{* * *}$ & $0.0724^{* * *}$ \\
\hline & $(0.00)$ & $(0.00)$ & $(0.01)$ & $(0.01)$ & $(0.00)$ \\
\hline \multirow[t]{2}{*}{ lnHhi_output Def } & $-0.0341^{* * *}$ & $-0.0198^{* * *}$ & -0.000394 & $-0.00787^{* *}$ & -0.00603 \\
\hline & $(0.00)$ & $(0.00)$ & $(0.88)$ & $(0.03)$ & $(0.11)$ \\
\hline \multirow[t]{2}{*}{ is_state } & $-0.104^{*}$ & $-0.151^{* * *}$ & -0.0232 & 0.0249 & $0.0447^{*}$ \\
\hline & $(0.10)$ & $(0.00)$ & $(0.21)$ & $(0.36)$ & $(0.10)$ \\
\hline \multirow[t]{2}{*}{ is_foreign } & $-0.0649^{* * *}$ & $-0.0369^{* *}$ & $0.0113^{*}$ & $-0.0186^{* *}$ & $-0.0208^{* *}$ \\
\hline & $(0.00)$ & $(0.03)$ & $(0.08)$ & $(0.05)$ & $(0.03)$ \\
\hline \multirow[t]{2}{*}{ is_private } & 0.0529 & 0.0315 & -0.000873 & 0.0198 & 0.00244 \\
\hline & $(0.11)$ & $(0.23)$ & $(0.93)$ & $(0.17)$ & $(0.87)$ \\
\hline \multirow[t]{2}{*}{ Constant } & $12.76^{* * *}$ & $11.25^{* * *}$ & $-0.362^{* * *}$ & $0.881^{* * * *}$ & $0.997^{* * *}$ \\
\hline & $(0.00)$ & $(0.00)$ & $(0.00)$ & $(0.00)$ & $(0.00)$ \\
\hline Firm-fixed effect & Yes & Yes & Yes & Yes & Yes \\
\hline Year-fixed effect & Yes & Yes & Yes & Yes & Yes \\
\hline Observations & 144,832 & 144,832 & 144,832 & 144,832 & 144,832 \\
\hline R-squared & 0.040 & 0.022 & 0.027 & 0.056 & 0.024 \\
\hline Number of firm & 51,538 & 51,538 & 51,538 & 51,538 & 51,538 \\
\hline
\end{tabular}

Note: parentheses report the regression coefficient P value, ${ }^{* * *},{ }^{* *},{ }^{*}$, respectively represent level $1 \%, 5 \%$ and $10 \%$. 
The positive effect of the total factor productivity lnTFP significantly in total enterprise exports and dual margins, indicates that the higher the enterprise productivity, the deeper margins of enterprise original export, and the more new export market and new export product category. The regression result of dual margins shows that the improvement of enterprise productivity can bring export growth, in which the intensive margin contribution is $49 \%$, and the extensive margin is $51 \%$. The multi-product firm model hypothesis reveals the underestimate contribution of extensive margin, compared with the single product model result.

The regression results of capital intensity lnCapital Intensity and enterprise exports is significant negative correlated, and respectively negative correlative with export intensive margin and extensive margin significantly. The result is consistent with the previous expectations: enterprise that is more capital intensive, its export is more capital intensive, which does not conform to China's comparative advantage in the international market, which is not conducive to the enterprises in the export market expansion. Technical intensity lnSkill Intensity, shows a significant positive correlation with the enterprise's exports, and the export intensive margin and the extensive margin are significantly positive correlated. It is worth noting that the contribution of technology intensive to the export of enterprises, in which the contribution ratio of the intensive margin was $41 \%$, while the contribution of extensive margin was 59\%. This is consistent with our impression of China's exports: China has high quality and cheap labor resources, which products have a comparative advantage in the international market, easy to enter the market of trading partners.

Markup, lnMarkup reflects the profitability of enterprises and in the market price, and the relative advantage position in market charging. Consistent with expectations, there is significant positive correlation between markup and enterprise's total exports and dual margins The Herfindahl index lnHhi_output Def reflects market competition and market structure, the regression results show that the higher the degree of market concentration, export enterprises will significantly lower the export intensive margin and the number of export destination. A possible explanation is that when the Herfindahl index is high, the more the capacity concentrated in the hands of a few large enterprises, then in the face of import competition pressure, large enterprises are forced to reduce production capacity, so that the export dual margins decreased.

The three dummy variables which reflected the enterprise ownership show that, state-owned enterprises export intensity is lower than other enterprises, the possible explanation is state-owned enterprises on the domestic market has a higher share, thus the export market participation enthusiasm would be rather low, inferior to other ownership enterprise in the export market competition. The dual margins o of foreign enterprises are significantly negative at the $5 \%$ significant level, which shows that the business of foreign enterprises is more in favor of the domestic market, not to export products. Finally, the dummy variable represented the private enterprises is not significant in dual margins of export, but the coefficients of them are positive. It shows that private enterprises have no obvious advantage in the export market.

\section{Conclusions}

This paper studies the relationship between import competition and export dual margins of multi-product firm. Using 2000-2006 industrial databases and customs database matching panel data set, with regression of twoway fixed effect panel data model, it is found that import competition significantly increased the intensive and extensive margin of multi-product firms' export, more stronger to the intensive margin.

The policy implication of this paper is releasing import restrictions and promoting import trade liberalization, although it will increase the degree of competition in the domestic market, but it will help local enterprises to improve their international competitiveness. In a protected market environment, firms lack sufficient power to understand the market situation, improve the level of production technology, improve product quality and develop more popular products. It is the time for China's manufacturing industry to upgrade, and the power of economic growth will be more relying on the expansion of domestic demand. The quality of China products has been recognized in the world market, but local producers in the domestic market are confronting foreign competitors. China can rely on the existing comparative advantages to transit competitive pressures in the domestic market into the power on the export market (Table 1).

\section{References}

[1] Bernard, A.B., Redding, S.J. and Schott, P.K. (2011) Multiproduct Firms and Trade Liberalization. The Quarterly Journal of Economics, 126, 1271-1318. http://dx.doi.org/10.1093/qje/qjr021 
[2] Decramer, S., Fuss, C. and Konings, J. (2014) How Do Exporters React to Changes in Cost Competitiveness? National Bank of Belgium, Brussels.

[3] Miranda, V., Badia, M.M. and Beveren, I.V. (2012) Globalization Drives Strategic Product Switching. IMF Working Paper WP/08/246. http://dx.doi.org/10.1007/s10290-011-0114-x

[4] Tybout, J.R. (2008) Chapter 13. Plant- and Firm-Level Evidence on "New” Trade Theories. In: Choi, E.K. and Harrigan, J., Eds., Handbook of International Trade, Blackwell Publishing Ltd., Oxford.

[5] Melitz, M.J. (2003) The Impact of Trade on Intra-Industry Reallocations and Aggregate Industry Productivity. Econometrica, 71, 1695-1725. http://dx.doi.org/10.1111/1468-0262.00467

[6] Harrison, A.E. (1994) Productivity, Imperfect Competition and Trade Reform: Theory and Evidence. Journal of International Economics, 36, 53-73. http://dx.doi.org/10.1016/0022-1996(94)90057-4

[7] Olley, G.S. and Pakes, A. (1996) The Dynamics of Productivity in the Telecommunications Equipment Industry. Econometrica, 64, 1263-1297. http://dx.doi.org/10.2307/2171831

[8] Hsieh, C.T. and Klenow, P.J. (2009) Misallocation and Manufacturing TFP in China and India. Quarterly Journal of Economics, 124, 1403-1448. http://dx.doi.org/10.1162/qjec.2009.124.4.1403 